\title{
Role of milk protein-based products in some quality attributes of goat milk yogurt
}

\author{
A. Gursel, ${ }^{* 1}$ A. Gursoy, ${ }^{*}$ E. A. K. Anli, ${ }^{*}$ S. O. Budak, ${ }^{*}$ S. Aydemir, $†$ and F. Durlu-Ozkayał \\ *Department of Dairy Technology, Faculty of Agriculture, Ankara University, 06110 Ankara, Turkey \\ †Enka Dairy and Food Products Industry and Commerce Ltd., 42150 Konya, Turkey \\ ‡Department of Gastronomy and Culinary Arts, Faculty of Tourism, Gazi University, 06830 Gölbaşı, Ankara, Turkey
}

\begin{abstract}
Goat milk yogurts were manufactured with the fortification of $2 \%$ (wt/vol) skim goat milk powder (SGMP), sodium caseinate $(\mathrm{NaCn})$, whey protein concentrate (WPC), whey protein isolate (WPI), or yogurt texture improver (YTI). Yogurts were characterized based on compositional, microbiological, and textural properties; volatile flavor components (with gas chromatography); and sensory analyses during storage (21 $\mathrm{d}$ at $5^{\circ} \mathrm{C}$ ). Compared with goat milk yogurt made by using SGMP, the other goat milk yogurt variants had higher protein content and lower acidity values. Goat milk yogurts with $\mathrm{NaCn}$ and WPC, in particular, had better physical characteristics. Using WPI caused the hardest structure in yogurt, leading to higher syneresis values. Acetaldehyde and ethanol formation increased with the incorporation of WPI, WPC, or YTI to yogurt milk. The tyrosine value especially was higher in the samples with $\mathrm{NaCn}$ and YTI than in the samples with WPC and WPI. Counts of Streptococcus thermophilus were higher than the counts of Lactobacillus delbrueckii ssp. bulgaricus, possibly due to a stimulatory effect of milk protein-based ingredients other than SGMP on the growth of S. thermophilus. Yogurt with $\mathrm{NaCn}$ was the best accepted among the yogurts. For the parameters used, milk protein-based products such as $\mathrm{NaCn}$ or WPC have promising features as suitable ingredients for goat milk yogurt manufacture.
\end{abstract}

Key words: goat milk yogurt, fortification, milk protein-based ingredient, quality attribute

\section{INTRODUCTION}

Yogurt has been one of the most accepted fermented milk products in the Turkish diet since the tribal period

Received September 14, 2015.

Accepted December 25, 2015.

${ }^{1}$ Corresponding author: gursel@agri.ankara.edu.tr because of its nutritious and health-beneficial characteristics. Cow, sheep, and goat milk can be used for yogurt manufacture alone or as a mixture. Sheep milk have higher TS content than cow and goat milk; therefore, using sheep milk gives good textural characteristics to yogurt, whereas yogurt from goat milk presents poor textural characteristics and has a gel structure susceptible to rupture due mainly to differences in protein composition between goat and cow milk (Remeuf and Lenoir, 1986; Agnihotri and Prasad, 1993; Park et al., 2007; Domagala, 2009). Despite its negative aspects, goat milk has been regarded as an indispensable raw material in the dairy technology thanks to its digestive quality; nutritional value in the diet of babies, children, and adults; and its beneficial physiological effects on those who suffer from malnutrition and indigestion (Haenlein, 2004; Raynal-Ljutovac et al., 2008; Riberio and Riberio, 2010).

Physical, textural, and sensory properties are important quality attributes in yogurt that directly affected consumer preference and product acceptability (Guichard, 2002). Among others, TS and total protein (TP) contents of milk are determinative factors for the quality characteristics of yogurt. Increasing TS by adding skim milk powder into milk is a common application in the yogurt technology, which prevents undesirable textural properties such as weak gel structure and syneresis (Tamime and Robinson, 2007). Apart from this, it is possible to increase TS and TP contents by means of evaporation and ultrafiltration techniques, or by adding hydrocolloids and milk protein-based products (Fiszman et al., 1999; Guzman-Gonzales et al., 2000; Isleten and Karagul-Yuceer, 2006; Guggisberg et al., 2007; Damin et al., 2009; Singh and Byars, 2009). Substitution of skim milk powder by milk protein-based products affects proteolytic activities of yogurt bacteria by creating differences in the protein content of milk and protein fractions (Kang et al., 1988; Mistry and Hassan, 1992), and peptides and AA released by the proteolytic breakdown of milk proteins can cause changes in the physical structure of yogurt. Furthermore, these products contribute to the typical taste and aroma via 
chemical reactions that lead to the formation of flavor compounds in yogurt (Tamime and Robinson, 2007).

Previous studies have been reported on improving physical, textural, and sensory properties of yogurt by incorporating the milk protein-based products or manipulation of processing parameters. Guzman-Gonzales et al. (2000) studied the effect of skim milk concentrate replacement by different dry dairy products in a low-fat set-type yogurt model system. They used skim milk concentrate as a milk base for manufacturing yogurt by enrichment of the protein content up to $43 \mathrm{~g} / \mathrm{kg}$ with caseinates, co-precipitate, and blended dairy powders. They concluded that yogurts enriched with caseinates had higher viscosity and syneresis index than yogurts made from concentrated skim milk fortified with coprecipitate. Herrero and Requena (2006) investigated the effect of supplementing goat milk with $30 \mathrm{~g} / \mathrm{L}$ of whey protein concentrate (WPC) for set-type yogurt manufacture; they reported that WPC enhanced the firmness, hardness, and adhesiveness, yielding a product maintaining these characteristics throughout a $28-\mathrm{d}$ storage period. In another study, Isleten and KaragulYuceer (2006) made nonfat yogurt by incorporation of whey protein isolate (WPI), sodium caseinate $(\mathbf{N a C n})$, and yogurt texture improver (YTI) into milk to provide better physical and sensory properties. They showed that WPI improved the physical properties of yogurt, resulting the highest viscosity and the lowest syneresis, but created the lowest fermented flavor attribute in the product. The authors concluded that yogurts fortified with $\mathrm{NaCn}$ and YTI were the most preferred samples by Turkish consumers. Recently, Akalın et al. (2012) reported that fortification of milk with $2 \%$ of sodium calcium caseinate gave better textural characteristics to probiotic yogurts prepared with Bifidobacterium lactis Bb12.

In some of these studies, skim cow milk has been used as the raw material, whereas whey protein concentrates have been used in some others. In some other studies, stirred-type yogurt samples have been used as the trial material. However, investigations on the use of additives based on milk-protein products in set-type goat milk yogurts have been rare in the literature. In this study, due to functional properties in enhancing physical and sensory properties, CN- and whey-protein-based products were used for the manufacture of goat milk yogurt. The objectives of the present paper were to study the effects of different milk protein-based products on the chemical, physical, microbiological, and sensory properties of goat milk yogurt during storage for $21 \mathrm{~d}$ at $5^{\circ} \mathrm{C}$.

\section{MATERIALS AND METHODS}

\section{Yogurt Treatments}

Five yogurt treatments were made as follows: control yogurt made by the addition of skim goat milk powder (SGMP), and yogurts made by the addition of $\mathrm{NaCn}$, WPC, WPI, or YTI at the rate of $2 \%$ ( $\mathrm{vol} / \mathrm{vol})$.

\section{Materials}

Goat milk (GM) and SGMP were supplied by Enka Dairy and Food Products Industry and Commerce Ltd. Co. (Konya, Turkey). The NaCn, WPC, WPI, and YTI were purchased from Arla Foods Company (Ingredients Group P/S, Viby J, Denmark). Chemical compositions of GM and milk protein-based ingredients are given in Table 1.

\section{Yogurt Culture Preparation}

The DVS freeze-dried yogurt culture (YO-MIX 572, Danisco-DuPont Group, Copenhagen, Denmark) containing Streptococcus thermophilus and Lactobacillus delbrueckii ssp. bulgaricus was used for manufacturing the experimental yogurts. The manufacturer's instruction was followed when using the culture. For each batch of yogurt base mixture (12 L), $0.24 \mathrm{~g}$ of starter culture was used. The culture was first transferred to approximately $250 \mathrm{~mL}$ of yogurt milk, mixed thoroughly, and then added to milk base.

Table 1. Composition (means $\pm \mathrm{SD}$ ) of goat milk and milk protein-based products used for the manufacture of yogurt mixes ${ }^{1}$

\begin{tabular}{|c|c|c|c|c|c|c|}
\hline Component (\%) & $\begin{array}{l}\text { Goat } \\
\text { milk }\end{array}$ & $\begin{array}{l}\text { Skim goat } \\
\text { milk powder }\end{array}$ & $\begin{array}{l}\text { Sodium } \\
\text { caseinate }\end{array}$ & $\begin{array}{l}\text { Whey protein } \\
\text { concentrate }\end{array}$ & $\begin{array}{l}\text { Whey protein } \\
\text { isolate }\end{array}$ & $\begin{array}{l}\text { Yogurt texture } \\
\text { improver }\end{array}$ \\
\hline $\mathrm{TS}$ & $12.13 \pm 0.41$ & 96.02 & $\geq 94$ & $\geq 94$ & $\geq 94$ & $\geq 94$ \\
\hline Fat & $3.90 \pm 0.35$ & 0.50 & $\leq 1.5$ & $\overline{\leq} 10.0$ & $\leq 0.2$ & $\leq 7.0$ \\
\hline Ash & $\mathrm{ND}^{2}$ & 7.68 & $\leq 4$ & $\leq 3.5$ & $\leq 4.5$ & $\leq 7$ \\
\hline
\end{tabular}

${ }^{1}$ Data for goat milk are the averages of triplicates; data for milk protein-based products are given by manufacturers.

${ }^{2} \mathrm{ND}=$ not determined. 


\section{Yogurt Manufacture}

Yogurt samples were produced in a commercial dairy plant (Enka Dairy and Food Products Industry and Commerce Ltd., Konya/Türkiye). For preparation of yogurt base mix, fresh GM with $3.6 \%$ fat (wt/vol) was standardized to $17 \%$ (wt/vol) solids nonfat by the addition of SGMP at $50^{\circ} \mathrm{C}$. The mix was then divided into 5 equal portions. One part was fortified with $2 \%$ (wt/ vol) of SGMP (control), and the other 4 parts were supplemented by incorporation of $\mathrm{NaCn}$, WPC, WPI, and YTI at the same rate as with SGMP. Single-stage homogenization was applied to each different batch of mixture at $15 \mathrm{MPa}$ at $70^{\circ} \mathrm{C}$. Mixes were heated to $90^{\circ} \mathrm{C}$ for $5 \mathrm{~min}$, rapidly cooled to $50^{\circ} \mathrm{C}$, inoculated with yogurt culture at $45^{\circ} \mathrm{C}$, dispensed into $200 \mathrm{~g}$ of plastic containers and incubated at $42^{\circ} \mathrm{C}$ until the $\mathrm{pH}$ reached 4.7. When the $\mathrm{pH}$ dropped to this point, yogurts were removed from incubation room, placed in cold storage at $5^{\circ} \mathrm{C}$, then transported in a cold chain from dairy plant to the laboratory of Dairy Technology Department, Ankara University. Analysis of yogurt samples was performed at $\mathrm{d} 1,7,14$, and 21 of cold storage $\left(5^{\circ} \mathrm{C}\right)$. Yogurts were manufactured in triplicate every $15 \mathrm{~d}$, with each replicate using $12 \mathrm{~L}$ of milk for each treatment.

\section{Physical, Chemical, and Microbiological Analyses}

The TP was analyzed by the Kjeldahl method (IDF, 1993) using the Büchi K435 digestion system and distillation unit (Büchi 323, Flawil, Switzerland). A multiplication factor of 6.38 was used for converting percent nitrogen to percent protein. The TS were estimated according to the AOAC International (1997) method. Fat was analyzed by the Gerber method (Renner, 1993). The $\mathrm{pH}$ value was measured by electrode immersion with a pH meter (MP225, Mettler-Toledo, Greifensee, Switzerland). Titratable acidity of the yogurts was determined according to the method reported by Bradley et al. (1993). Tyrosine value was determined by the spectrophotometric method described by Hull (1947). These determinations were performed in duplicate.

Syneresis was evaluated according to Robitaille et al. (2009) by a centrifugation (Sigma $3-18 \mathrm{~K}$, Osterode am Harz, Germany) of $25 \mathrm{~g}$ of yogurt at $600 \times g$ for $10 \mathrm{~min}$ at $4^{\circ} \mathrm{C}$. Syneresis (\%) was calculated by the weight of supernatant after centrifugation and the weight of the yogurt.

Enumeration of $S$. thermophilus and L. delbrueckii ssp. bulgaricus was performed according to the procedures outlined by the International Dairy Federation Standard for fermented milk (IDF, 1997), by pour plating on M17 agar and de Man, Rogosa and Sharpe agar, respectively. All bacterial counts were conducted in duplicate.

\section{Texture Analysis}

A texture analyzer TA.XTPlus (Stable Micro Systems, Surrey, UK) was used for quantifying the hardness (the force required to attain a given deformation) of a yogurt sample. The test was carried out directly in a 200-g plastic sample cup, immediately after removing the sample from refrigerator, using a $45-\mathrm{mm}$ back extrusion cone and a 5 -kg load cell. A cone probe was moved at a test speed of $10 \mathrm{~mm} / \mathrm{s}$ from the yogurt surface until a distance of $20 \mathrm{~mm}$ within the sample was reached. Four measurements were made with each of the samples in different cups.

\section{Determination of Volatile Flavor Compounds}

Volatile flavor compounds were determined by head space technique as reported by Ulberth (1991) with a GC (Agilent 6890 series, Santa Clara, CA) system using a flame ionization detector, and $30 \mathrm{~m} \times 320 \mu \mathrm{m}$ (internal diameter) polyethylene glycol capillary column with $0.25-\mu \mathrm{m}$ film thickness (HP Innowax, Agilent Technologies, Santa Clara, CA). Briefly, 5 g of yogurt sample was weighed into $20-\mathrm{mL}$ headspace vials and capped using a crimper. Samples were stored at $-20^{\circ} \mathrm{C}$ until they were used. Before introducing samples to the GC, they were held at $80^{\circ} \mathrm{C}$ for $20 \mathrm{~min}$ in an oven. Air on top of the sample in vial was injected to GC with a $1,000 \mu \mathrm{L}$ of a gas-tight syringe. All injections were made in triplicate. Injector block temperature was $80^{\circ} \mathrm{C}$ and the flame ionization detector temperature was $260^{\circ} \mathrm{C}$. Flow rates for make-up gas (nitrogen), hydrogen, and air were 30 , 40 , and $400 \mathrm{~mL} / \mathrm{min}$, respectively. The carrier gas was helium with a flow rate of $0.7 \mathrm{~mL} / \mathrm{min}$. The oven was held at $80^{\circ} \mathrm{C}$ for $1 \mathrm{~min}$, the temperature was increased at $5^{\circ} \mathrm{C}$ per min to $170^{\circ} \mathrm{C}$ and held for $1 \mathrm{~min}$, and then to a final temperature of $210^{\circ} \mathrm{C}$ at $10^{\circ} \mathrm{C}$ per min to give a run time of 15 min. A series of calibration solutions were prepared at the concentrations of $10,25,50,75$, and $100 \mathrm{mg} / \mathrm{L}$ for each flavor compound. Calibration curves were constructed for each calibration solution by plotting the peak area against the mass of the flavor compounds.

\section{Sensory Analysis}

Sensory analysis was performed by 7 panelists from academic staff of the Dairy Technology Department 
MILK PROTEIN-BASED PRODUCTS

Table 2. Main physicochemical characteristics (means \pm SD) of yogurts fortified with various milk protein-based products

\begin{tabular}{|c|c|c|c|c|c|}
\hline Treatment $^{1}$ & $\begin{array}{c}\text { TS } \\
(\%)\end{array}$ & $\begin{array}{c}\text { Total protein } \\
(\%)\end{array}$ & $\begin{array}{l}\text { Fat } \\
(\%)\end{array}$ & $\mathrm{pH}$ & $\begin{array}{c}\text { Titratable acidity } \\
(\% \text { lactic acid })\end{array}$ \\
\hline$\overline{\text { SGMPY }}$ & $20.14 \pm 0.22^{\mathrm{a}}$ & $6.36 \pm 0.05^{\mathrm{d}}$ & $3.73 \pm 0.23^{\mathrm{a}}$ & $4.48 \pm 0.06^{\mathrm{c}}$ & $1.8 \pm 0.00^{\mathrm{a}}$ \\
\hline $\mathrm{NaCnY}$ & $19.76 \pm 0.31^{\mathrm{ab}}$ & $7.38 \pm 0.08^{\mathrm{a}}$ & $3.67 \pm 0.12^{\mathrm{a}}$ & $4.57 \pm 0.04^{\mathrm{ab}}$ & $1.7 \pm 0.00^{\mathrm{b}}$ \\
\hline WPIY & $19.76 \pm 0.18^{\mathrm{ab}}$ & $7.49 \pm 0.07^{\mathrm{a}}$ & $3.73 \pm 0.23^{\mathrm{a}}$ & $4.61 \pm 0.02^{\mathrm{a}}$ & $1.6 \pm 0.00^{\mathrm{c}}$ \\
\hline YTIY & $19.70 \pm 0.23^{\mathrm{ab}}$ & $6.60 \pm 0.05^{\mathrm{c}}$ & $3.73 \pm 0.12^{\mathrm{a}}$ & $4.62 \pm 0.04^{\mathrm{a}}$ & $1.5 \pm 0.00^{\mathrm{d}}$ \\
\hline
\end{tabular}

${ }^{\mathrm{a}-\mathrm{d}}$ Means $\pm \mathrm{SD}$ in the same column with different superscript letters differ $(P<0.01)$.

${ }^{1} \mathrm{SGMPY}=$ yogurt fortified with skim goat milk powder; $\mathrm{NaCnY}=$ yogurt fortified with sodium caseinate; WPCY $=$ yogurt fortified with whey protein concentrate; WPIY = yogurt fortified with whey protein isolate; YTIY = yogurt fortified with yogurt texture improver. Values within the columns are the averages of $\mathrm{d} 1$ to 21 in triplicate.

(Ankara University, Ankara, Turkey) who had previous experience in yogurt evaluation and regularly consume yogurt in their diets. Yogurts were evaluated according to the scoring card described by Bodyfelt et al. (1988) and Tribby (2009) with some modifications. The score card included only those attributes that are expected to arise from using GM and the milk protein-based products used for manufacturing yogurt. Additionally, some sensory attributes detected in the pre-experimental samples by the panelists were involved in the card. Panelists were requested to evaluate color/appearance, body/texture, and odor/flavor and to note any perceived defects in sensory attributes (uneven, unnatural, shrinkage, wheying-off, microbial growth on the surface for color/appearance; lumpy, grainy, coarse, too firm, too weak, wheying-off for body/texture; cooked, creamy, salty, whey-like, foreign, too acid, sweet, astringent, lacks typical yogurt flavor, yeasty for odor/ flavor). Mean scores were used for comparison of the samples. The samples were randomly coded and were removed from refrigerator $1 \mathrm{~h}$ before beginning the evaluation session. Each yogurt was served in a $200-\mathrm{g}$ plastic cup fitted with lid, together with distilled water to panelists placed separately in rooms for unbiased evaluation of sensory attributes.

\section{Statistical Analysis}

A randomized complete block design that incorporated 5 treatments, 4 storage periods, and 3 blocks (trials) was used to analyze the response variables relating to characteristics of yogurt. An ANOVA was performed using the Minitab statistical package (version 15.0, Minitab Inc., State College, PA) to identify significant differences between the evaluated responses. Duncan's multiple-comparison test was used a guide for comparisons of treatment means. The level of significance of differences between treatments was determined at $P<$ 0.05 and $P<0.01$.

\section{RESULTS AND DISCUSSION}

\section{Composition of Yogurts}

Table 2 shows the average composition of GM yogurts fortified with various milk protein-based products. The yogurts with NaCn, WPC, WPI, and YTI had slightly lower values of TS, and higher values of TP than the yogurt with SGMP throughout the storage $(P$ $<0.01)$. These differences were related to the different fortification substrates (Table 1) used for preparation of yogurts.

The titratable acidity was lower, and the $\mathrm{pH}$ value was greater in the samples fortified with $\mathrm{NaCn}$, WPC, WPI, and YTI than in the sample fortified with SGMP $(P<0.01$; Table 2$)$. Similar values for titratable acidity $(P>0.01)$ in the yogurt fortified with WPC or WPI may be explained by the increase of buffering capacity of yogurt mixes due to the added whey proteins. Lee and Lucey (2010) concluded that fortification with whey proteins leads to an increase in the solid content of yogurt milk, thereby creating an increase in buffering capacity that requires additional acid development by starter cultures to achieve a similar $\mathrm{pH}$ target. The $\mathrm{pH}$ values did not change throughout the storage, but titratable acidity increased slightly at d $21(P<0.01)$.

\section{Proteolysis in Yogurt Samples}

The degree of proteolysis in yogurts was estimated by tyrosine value, and data are shown in Table 3. Treatment by time interactions were significant for tyrosine values $(P<0.05)$. In general, tyrosine value increased until d 14 in all yogurt samples, then decreased slightly in especially the yogurts fortified with $\mathrm{NaCn}$ and WPC, as in the yogurt fortified with SGMP. The lowest value of tyrosine was obtained with the fortification of WPI for all days of storage. Changes in tyrosine value of the yogurt with WPC were similar $(P>0.05)$ to that of the yogurt fortified with YTI among d 1, 7, and 14 . 
Table 3. Tyrosine value (mg/g; means $\pm \mathrm{SD}$ ) of yogurts fortified with various milk protein-based products

\begin{tabular}{|c|c|c|c|c|}
\hline \multirow[b]{2}{*}{ Treatment $^{1}$} & \multicolumn{4}{|c|}{ Time (d) } \\
\hline & 1 & 7 & 14 & 21 \\
\hline $\begin{array}{l}\text { SGMPY } \\
\text { NaCnY } \\
\text { WPCY } \\
\text { WPIY } \\
\text { YTIY }\end{array}$ & $\begin{array}{l}0.393 \pm 0.017^{\mathrm{a}, \mathrm{B}} \\
0.279 \pm 0.014^{\mathrm{b}, \mathrm{C}} \\
0.254 \pm 0.006^{\mathrm{b}, \mathrm{C}} \\
0.239 \pm 0.004^{\mathrm{b}, \mathrm{B}} \\
0.283 \pm 0.012^{\mathrm{b}, \mathrm{B}}\end{array}$ & $\begin{array}{l}0.456 \pm 0.007^{\mathrm{a}, \mathrm{A}} \\
0.354 \pm 0.016^{\mathrm{b}, \mathrm{B}} \\
0.303 \pm 0.018^{\mathrm{bc}, \mathrm{BC}} \\
0.285 \pm 0.002^{\mathrm{c}, \mathrm{AB}} \\
0.328 \pm 0.012^{\mathrm{bc}, \mathrm{AB}}\end{array}$ & $\begin{array}{l}0.452 \pm 0.008^{\mathrm{a}, \mathrm{A}} \\
0.414 \pm 0.029^{\mathrm{ab}, \mathrm{A}} \\
0.397 \pm 0.041^{\mathrm{b}, \mathrm{A}} \\
0.306 \pm 0.003^{\mathrm{c}, \mathrm{A}} \\
0.362 \pm 0.007^{\mathrm{b}, \mathrm{A}}\end{array}$ & $\begin{array}{l}0.384 \pm 0.026^{\mathrm{a}, \mathrm{B}} \\
0.389 \pm 0.022^{\mathrm{a}, \mathrm{AB}} \\
0.352 \pm 0.024^{\mathrm{ab}, \mathrm{AB}} \\
0.309 \pm 0.006^{\mathrm{b}, \mathrm{A}} \\
0.371 \pm 0.014^{\mathrm{a}, \mathrm{A}}\end{array}$ \\
\hline $\begin{array}{l}{ }^{-\mathrm{c}} \text { Means } \pm \\
{ }^{\mathrm{A}-\mathrm{C}} \text { Means } \pm \\
{ }^{1} \text { SGMPY }= \\
\text { WPCY = yo } \\
\text { YTIY = yog } \\
\text { analyzed in }\end{array}$ & $\begin{array}{l}\text { he same column } \\
\text { he same row wit } \\
\text { fortified with sk } \\
\text { tified with whey } \\
\text { tified with yogur } \\
\text { e. }\end{array}$ & $\begin{array}{l}\text { lifferent lowercase } \\
\text { erent uppercase let } \\
\text { at milk powder; } \\
\text { ein concentrate; W } \\
\text { ture improver. Me }\end{array}$ & $\begin{array}{l}\text { rs differ }(P<0.05 \\
\text { differ }(P<0.05) \text {. } \\
\mathrm{Y}=\text { yogurt fortif } \\
=\text { yogurt fortified } \\
\text { lues for each vari }\end{array}$ & $\begin{array}{l}\text { ith sodium caseir } \\
\text { whey protein iso } \\
\text { f yogurt in tripli }\end{array}$ \\
\hline
\end{tabular}

The TS and TP contents of milk may have an influence on the level of proteolysis besides such factors as proteolytic activity and ratio of strains in the starter culture, protocooperation between the 2 yogurt bacteria, and heating of milk (Rasic et al., 1971; Tamime and Deeth, 1980; Slocum et al., 1988). Tramer (1973) reported that TS content over $21 \%$ inhibits culture growth, particularly growth of L. delbrueckii ssp. bulgaricus, which would lead to a decrease in proteolysis. On the other hand, Slocum et al. (1988) observed an increase in proteolysis with increasing level of TS up to $14 \%$, then a decrease beyond $14 \%$. The authors reported that culture growth may be prolonged rather than being inhibited at TS level between 12.5 and $14.5 \%$ due possibly to the buffering capacity of protein at these ranges. In the present study, despite the fact that all yogurt samples had TS over $14 \%$, tyrosine value tended to increase during storage. Moreover, tyrosine value was significantly $(P<0.01)$ higher in the yogurt with $\mathrm{NaCn}$

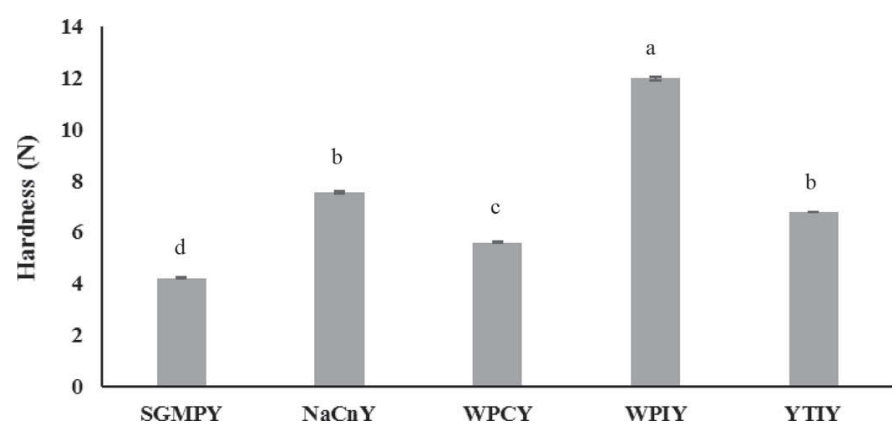

Figure 1. Hardness (N; mean $\pm \mathrm{SD}$ ) of yogurts fortified with various milk protein-based products. Bars represent the averages of $\mathrm{d} 1$ to 21 in triplicate. Error bars denote standard deviations. SGMPY = yogurt fortified with skim goat milk powder; $\mathrm{NaCnY}=$ yogurt fortified with sodium caseinate; WPCY = yogurt fortified with whey protein concentrate; WPIY = yogurt fortified with whey protein isolate; YTIY $=$ yogurt fortified with yogurt texture improver. Bars not sharing common letters $(\mathrm{a}-\mathrm{d})$ are different for treatments $(P<0.01)$. than in the yogurts with WPC and WPI on $\mathrm{d} 7,14$, and 21. The principal caseins in GM are about the same as in the cow milk; however, $\beta-\mathrm{CN}$ is the main $\mathrm{CN}$ fraction of GM (Park et al., 2007). According to Chandan et al. (1982), $\beta$-CN is hydrolyzed more readily than whey proteins by the enzymes released from yogurt bacteria. From the above results, it can be concluded that rate of proteolysis is dependent on the protein concentration available for hydrolysis rather than TS level as reported by Slocum et al. (1988).

Tyrosine level may play a role for indication of bitter taste development in yogurt. Asperger (1977) previously reported that bitter taste might become clear when the amount of tyrosine exceeded $0.5 \mathrm{mg} / \mathrm{mL}$ in yogurt. In this study, tyrosine level was below that threshold value in all 5 yogurt samples.

\section{Textural Characteristics and Syneresis of Yogurts}

Figure 1 shows the hardness value of GM yogurts fortified with various milk protein-based ingredients. Depending upon the type of additives, different behaviors were observed in hardness of the experimental yogurt samples. The yogurt with WPI showed the highest value for hardness, being depicted as excessively firm, though TS and TP contents were similar to that of the yogurt with $\mathrm{NaCn}$. Hardness was similar $(P>0.01)$ for the yogurts fortified with $\mathrm{NaCn}$ and YTI, but showed the lowest value in the yogurt fortified with SGMP. Li and Guo (2006) reported that yogurt from GM displays lower viscosity than yogurt from cow milk due pos-

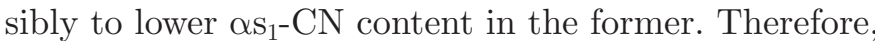
enrichment of GM with especially whey proteins has been highly recommended by Sullivan et al. (2008) and Wang et al. (2012) to obtain a gel network that can be less susceptible to rupture, and highly capable to immobilize aqueous phase in the matrix. In general, firmness of curd increases with increasing level of whey proteins 
(Puvanenthiran et al., 2002; Herrero and Requena, 2006; Isleten and Karagul-Yuceer, 2006; Domagala et al., 2007; Damin et al., 2009). However, Aziznia et al. (2008) reported that in yogurt supplemented with 7.5, 15 , and $20 \mathrm{~g} / \mathrm{L}$ of WPC, increasing amount of WPC $(>15 \mathrm{~g} / \mathrm{L})$ resulted in more open microstructure with markedly lumpy texture and greater syneresis than the lower concentrations due probably to the formation of extremely large whey protein aggregates between CN particles, resulting from altered process of gel formation during acidification. This would explain the differences in the present study between hardness value of the yogurt fortified with WPI and the yogurt fortified with $\mathrm{NaCn}$, WPC, or YTI. Hardness did not show notable changes among days of storage. Herrero and Requena (2006) stated that yogurt from GM supplemented with whey protein concentrate maintained its textural characteristics throughout a 28 -d storage period.

Whey syneresis data are shown in Figures $2 \mathrm{a}$ and $2 \mathrm{~b}$. Effect of treatment was significant $(P<0.01)$ on syneresis. Fortification of GM with YTI resulted in minimal syneresis. The samples with $\mathrm{NaCn}$ and SGMP had similar values for syneresis $(P>0.01)$. Syneresis increased when yogurt base mix was fortified with WPC or WPI, suggesting that increased concentrations of whey proteins proportionately to $\mathrm{CN}$ resulted in greater syneresis in yogurt (Puvanenthiran et al., 2002; Amatayakul et al., 2006; Wang et al., 2012). Modler et al. (1983) tried 6 protein types (3 CN and 3 wheybased products) and 3 different protein concentrations $(0.05,1.0$, and $1.5 \%)$ in yogurt. These authors found that syneresis decreased with increasing concentration of protein, and fortification of milk with $1.5 \% \mathrm{CN}$ was more effective to reduce yogurt syneresis than other milk protein-based ingredients. Storage period created significant $(P<0.05)$ differences in syneresis of all 5 yogurt samples (Figure 2b). The least syneresis was observed on d 21 in comparison with d 1 . This result accords with those of Barrantes et al. (1994), Isleten and Karagul-Yuceer (2006), and Domagala (2009) who observed decreasing level of syneresis at the end of storage due possibly to an increase in the water-holding capacity of gel matrix during storage.

\section{Volatile Flavor Compounds of Yogurts}

Table 4 shows the volatile flavor compounds that mainly differentiated the yogurts made from GM fortified with SGMP, NaCn, WPC, WPI, or YTI. By the fortification of milk with WPI and WPC, acetaldehyde concentration reached higher levels than by the fortifications with YTI, NaCn, and SGMP $(P<0.01)$. The addition of whey-protein-based products to yogurt milk means an increase in possible precursors in the pathway for the formation of acetaldehyde. The whey protein products are known to be rich in threonine and valine AA as compared with caseinates (Bucci and Unlu, 2000; Sindayikengera and Xia, 2006), which could be the reason for high acetaldehyde concentration in the experimental yogurts fortified with whey-protein-based additives. The breakdown of threonine to acetaldehyde and glycine via threonine aldolase seems to be the most important pathway for production of acetaldehyde in yogurt (Zouari et al., 1992; Routray and Mishra, 2011). Inhibition of the enzyme in the high glycine and low threonine media may lead to a low level of acetaldehyde formation in yogurt as it was observed by Rysstad et al. (1990) for yogurt from GM, which has higher glycine content than cow milk. However, threonine aldolase activity of yogurt bacteria, particularly activity of the enzyme in $S$. thermophilus, can be stimulated by increasing the threonine concentration in the growth medium (Wilkins et al., 1986; Rysstad et al., 1990). Marshall and El-Bagoury (1986) observed an increase in the acetaldehyde content of GM yogurt made from
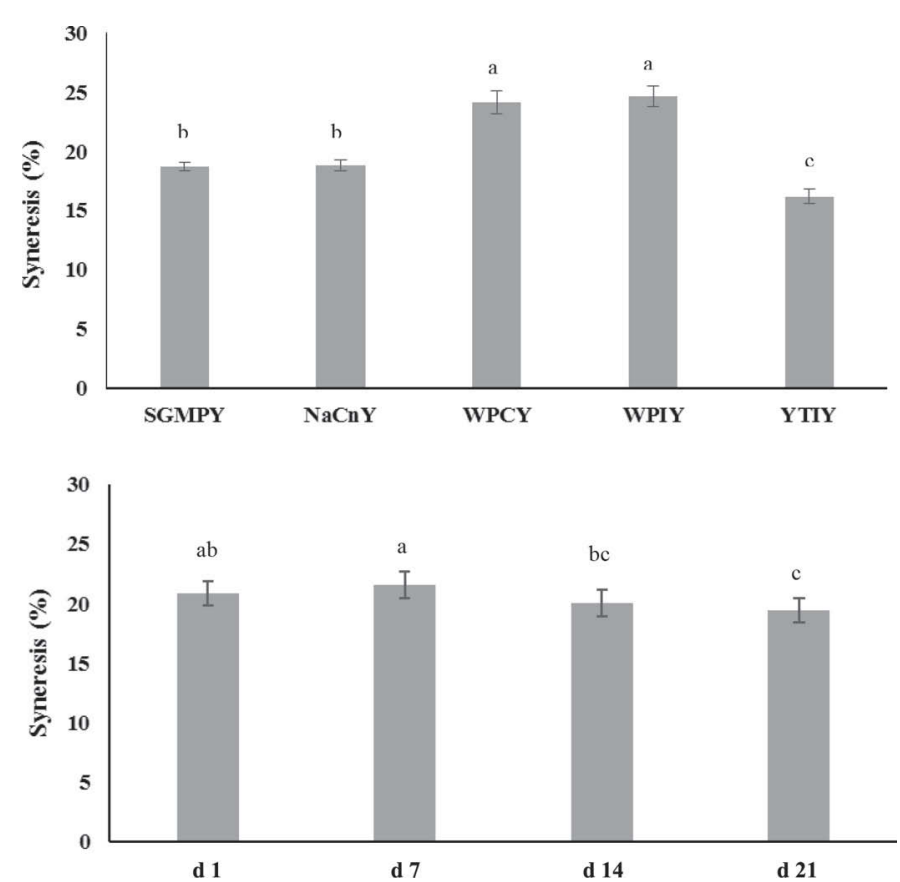

Figure 2. (a) Syneresis (\%; mean $\pm \mathrm{SD}$ ) of yogurts fortified with various milk protein-based products. Bars represent the averages of $\mathrm{d}$ 1 to 21 in triplicate. Bars not sharing common letters $(\mathrm{a}-\mathrm{c})$ are different for treatments $(P<0.01)$. (b) Changes in syneresis $(\%$; mean $\pm \mathrm{SD}$ ) during storage of yogurts fortified with various milk proteinbased products. Bars represent the averages of 5 treatments in triplicate. Bars not sharing common letters $(\mathrm{a}-\mathrm{c})$ are different for storage period $(P<0.05)$. SGMPY $=$ yogurt fortified with skim goat milk powder; $\mathrm{NaCnY}=$ yogurt fortified with sodium caseinate; WPCY = yogurt fortified with whey protein concentrate; WPIY = yogurt fortified with whey protein isolate; YTIY = yogurt fortified with yogurt texture improver. 
Table 4. Volatile flavor compounds $(\mathrm{mg} / \mathrm{kg}$; means $\pm \mathrm{SD}$ ) of yogurts fortified with various milk protein-based products

\begin{tabular}{lcccc}
\hline Item & Acetaldehyde & Acetoin & Butanone- & Ethanol \\
\hline Treatment $^{1}$ & $1.94 \pm 0.12^{\mathrm{d}}$ & $0.37 \pm 0.14^{\mathrm{a}}$ & $1.15 \pm 0.04^{\mathrm{a}}$ & $1.51 \pm 0.23^{\mathrm{c}}$ \\
SGMPY & $2.62 \pm 0.17^{\mathrm{d}}$ & $0.31 \pm 0.12^{\mathrm{a}}$ & $1.14 \pm 0.04^{\mathrm{a}}$ & $4.01 \pm 0.69^{\mathrm{b}}$ \\
NaCnY & $8.68 \pm 0.68^{\mathrm{b}}$ & $0.28 \pm 0.10^{\mathrm{a}}$ & $1.12 \pm 0.04^{\mathrm{a}}$ & $3.64 \pm 0.52^{\mathrm{b}}$ \\
WPCY & $11.99 \pm 0.55^{\mathrm{a}}$ & $0.42 \pm 0.12^{\mathrm{a}}$ & $1.16 \pm 0.03^{\mathrm{a}}$ & $5.82 \pm 0.82^{\mathrm{a}}$ \\
WPIY & $7.36 \pm 0.62^{\mathrm{c}}$ & $0.24 \pm 0.09^{\mathrm{a}}$ & $1.18 \pm 0.03^{\mathrm{a}}$ & $4.41 \pm 0.32^{\mathrm{ab}}$ \\
YTIY $_{\text {Time }^{2}(\mathrm{~d})}$ & $7.48 \pm 1.21^{\mathrm{A}}$ & $0.24 \pm 0.09^{\mathrm{B}}$ & $1.09 \pm 0.06^{\mathrm{B}}$ & $3.63 \pm 0.57^{\mathrm{AB}}$ \\
1 & $7.02 \pm 1.11^{\mathrm{AB}}$ & $0.72 \pm 0.13^{\mathrm{A}}$ & $1.12 \pm 0.03^{\mathrm{B}}$ & $4.61 \pm 0.75^{\mathrm{A}}$ \\
7 & $6.00 \pm 1.03^{\mathrm{BC}}$ & $0.12 \pm 0.03^{\mathrm{B}}$ & $1.15 \pm 0.02^{\mathrm{B}}$ & $3.19 \pm 0.55^{\mathrm{B}}$ \\
14 & $5.57 \pm 0.94^{\mathrm{C}}$ & $0.22 \pm 0.06^{\mathrm{B}}$ & $1.24 \pm 0.01^{\mathrm{A}}$ & $4.08 \pm 0.54^{\mathrm{AB}}$ \\
\hline
\end{tabular}

${ }^{\mathrm{a}-\mathrm{d}}$ Means $\pm \mathrm{SD}$ within the same column with different lowercase letters differ $(P<0.01)$.

${ }^{\mathrm{A}-\mathrm{C}}$ Means $\pm \mathrm{SD}$ within the same column with different uppercase letters differ $(P<0.05)$.

${ }^{1} \mathrm{SGMPY}=$ yogurt fortified with skim goat milk powder; $\mathrm{NaCnY}=$ yogurt fortified with sodium caseinate; $\mathrm{WPCY}=$ yogurt fortified with whey protein concentrate; WPIY = yogurt fortified with whey protein isolate; YTIY $=$ yogurt fortified with yogurt texture improver. Values within the columns are the averages of d 1 to 21 in triplicate.

${ }^{2}$ Values within the columns are the averages of 5 treatments in triplicate.

ultrafiltered milk by the addition of $0.1 \%$ threonine to yogurt mix. In this study, acetaldehyde concentration was similar for the yogurts fortified with $\mathrm{NaCn}$ and SGMP $(P>0.01)$, but presents significant differences among the samples with WPC, WPI, and YTI $(P<$ $0.01)$. This can be explained by the structural and compositional changes in yogurt matrix resulting from different types of milk proteins used for fortification. Saint-Eve et al. (2006) studied the aroma release of $4 \%$ fat flavored stirred yogurts enriched with sodium caseinate, low heat skim milk powder, or whey protein concentrate, and found that release of the majority of aroma compounds was lower in caseinate-enriched yogurt than in whey protein-enriched yogurt. Acetaldehyde concentration in yogurts decreased $(P<0.05)$ after storage for $21 \mathrm{~d}$ as observed previously by Gaafar (1992), Laye et al. (1993), and Hruskar et al. (1995). This is due to conversion of acetaldehyde to ethanol by alcohol dehydrogenase (Chaves et al., 2002). The enzyme has been reported to be found in S. thermophilus, but not found in L. delbrueckii ssp. bulgaricus (Lees and Jago, 1976; Marshall and Cole, 1983; Raya et al., 1986).

Among volatile flavor compounds, diacetyl could not be detected in some of the yogurt samples; therefore, values for diacetyl concentration were not given. Acetoin and butanone- 2 concentrations expressed similarities $(P>0.01)$ by the fortification of milk with various types of milk protein-based products, but showed differences among days of storage $(P<0.01)$. Higher level of acetoin was found at $\mathrm{d} 7$; thereafter, no significant changes were observed. Butanone-2 concentration reached the highest level at $d 21$. Similarly, changes in acetoin and butanone-2 concentrations were observed by some other researchers during shelf-life period of yogurt (Kondratenko and Gyosheva, 1978; Kang et al., 1988; Gaafar, 1992; Laye et al., 1993; Kwak, 1995). Ethanol concentration presented significant differences among all 5 yogurt samples. The highest concentration of ethanol $(P<0.01)$ was in the sample with WPI, whereas the lowest concentration $(P<0.01)$ was observed in the yogurt with SGMP. Yogurt samples with $\mathrm{NaCn}$ and WPC had similar concentrations of ethanol $(P>0.01)$. Ethanol content increased slightly at d 7 , though no significant difference was observed on $\mathrm{d} 21$ in comparison with d 1. Contrary to our findings, Gyosheva and Rusev (1979), Kang et al. (1988), and Kwak (1995) reported an increase in ethanol content during storage of yogurt.

\section{Viability of Yogurt Bacteria}

Figure 3 presents $S$. thermophilus and L. delbrueckii ssp. bulgaricus counts for yogurts. Fortification of GM with milk protein-based products created differences in the mean counts of $S$. thermophilus $(P<0.05)$. The yogurts with NaCn, WPC, WPI, and YTI had higher $(P<0.05)$ viable cells of streptococci than the yogurt with SGMP. On the other hand, observations on streptococcal counts revealed similarities $(P>$ 0.05 ) between the yogurts with $\mathrm{NaCn}$ and WPI, and with WPC and YTI. The mean count of streptococci increased until d $7(P<0.01)$, constant counts were observed thereafter, indicating that the presence of different milk protein-based products did not suppress $S$. thermophilus viability. Supplementation of yogurt milk created no significant $(P>0.05)$ effect on the mean counts of $L$. delbrueckii ssp. bulgaricus, but significant variations $(P<0.01)$ were found among days of stor- 


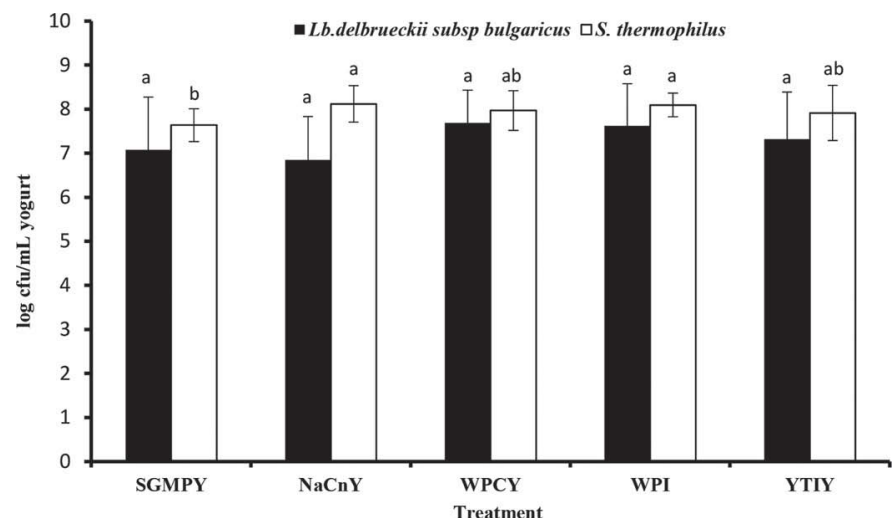

Figure 3. Microbial characteristics (in $\log \mathrm{cfu} / \mathrm{g}$ ) of yogurts fortified with various milk protein-based products. Black bars denote means of Lactobacillus delbrueckii ssp. bulgaricus, and white bars denote means of Streptococcus thermophilus counts over $21 \mathrm{~d}$ of storage in triplicate. SGMPY = yogurt fortified with skim goat milk powder; $\mathrm{NaCnY}=$ yogurt fortified with sodium caseinate; WPCY $=$ yogurt fortified with whey protein concentrate; WPIY = yogurt fortified with whey protein isolate; YTIY = yogurt fortified with yogurt texture improver. Bars not sharing common letters $(\mathrm{a}, \mathrm{b})$ are different for treatments $(P<0.05)$.

age. At the beginning, the mean numbers of viable cells of lactococci were $8.50 \pm 0.05 \log _{10} \mathrm{cfu} / \mathrm{g}$, declining by approximately $2 \log$ cycles after storage for $21 \mathrm{~d}(P<$ 0.01). Higher counts of $S$. thermophilus was apparent than the counts of $L$. delbrueckii ssp. bulgaricus in all 5 yogurts. This is probably due to the differences in the stimulatory effect of milk protein-based ingredients on growth of yogurt bacteria. According to McComas and Gilliland (2003), whey proteins have no inducible effect on growth of $L$. delbrueckii ssp. bulgaricus strains, and an effect on $S$. thermophilus depends upon the strain variability. Damin et al. (2009) investigated the effect of milk supplementation with skim milk powder, whey protein concentrate, or sodium caseinate on acidification kinetics, rheological properties, and structure of nonfat stirred yogurt; they showed that the viable number of $S$. thermophilus was greater than that of $L$. delbrueckii ssp. bulgaricus. Oliveira et al. (2001) also reported that in mixed cultures of $S$. thermophilus with Lactobacillus acidophilus or Lactobacillus rhamnosus; the former showed predominance under all culture conditions used for probiotic-fermented milk supplemented with CN hydrolysate.

\section{Sensory Evaluation}

Table 5 shows the results of organoleptic evaluation of yogurt samples. Fortification of GM with different milk protein-based products resulted in significant $(P$ $<0.01$ ) variations on judges' preferences for sensorial attributes of the samples. Panelists preferred the yogurt with $\mathrm{NaCn}$ more than the yogurt with WPC or YTI due to its bright color and appearance, and creamier body and texture, though the scores for these attributes were similar $(P>0.01)$ for all 3 yogurts. The yogurt with WPI had the lowest scores for color and appearance, and body and texture because of its hardest structure (Figure 1) with excessive whey separation (Figure 2a). Yogurt sample with WPC was the best perceived product with respect to odor and flavor, this was probably due to its mild acidity and aroma. Due to its salty and too acid taste, the yogurt with

Table 5. Sensory scores (means \pm SD) of yogurts fortified with various milk protein-based products

\begin{tabular}{|c|c|c|c|}
\hline \multirow[b]{2}{*}{ Item } & \multicolumn{3}{|c|}{ Sensorial property } \\
\hline & $\begin{array}{l}\text { Color and appearance } \\
\text { (maximum } 5 \text { points) }\end{array}$ & $\begin{array}{l}\text { Body and texture } \\
\text { (maximum } 5 \text { points) }\end{array}$ & $\begin{array}{c}\text { Odor and flavor } \\
\text { (maximum } 10 \text { points) }\end{array}$ \\
\hline \multicolumn{4}{|c|}{ Treatment $^{1}$} \\
\hline SGMPY & $4.19 \pm 0.08^{\mathrm{b}}$ & $3.18 \pm 0.15^{\mathrm{b}}$ & $5.88 \pm 0.38^{\mathrm{c}}$ \\
\hline $\mathrm{NaCnY}$ & $4.63 \pm 0.07^{\mathrm{a}}$ & $4.29 \pm 0.10^{\mathrm{a}}$ & $7.06 \pm 0.29^{\mathrm{ab}}$ \\
\hline WPCY & $4.56 \pm 0.07^{\mathrm{a}}$ & $4.09 \pm 0.10^{\mathrm{a}}$ & $7.81 \pm 0.30^{\mathrm{a}}$ \\
\hline WPIY & $3.91 \pm 0.08^{\mathrm{c}}$ & $2.85 \pm 0.09^{\mathrm{b}}$ & $5.59 \pm 0.24^{\mathrm{c}}$ \\
\hline YTIY & $4.53 \pm 0.09^{\mathrm{a}}$ & $3.95 \pm 0.10^{\mathrm{a}}$ & $7.02 \pm 0.17^{\mathrm{b}}$ \\
\hline \multicolumn{4}{|l|}{$\operatorname{Time}^{2}(\mathrm{~d})$} \\
\hline 1 & $4.29 \pm 0.08^{\mathrm{B}}$ & $3.84 \pm 0.14^{\mathrm{A}}$ & $6.25 \pm 0.34^{\mathrm{B}}$ \\
\hline 7 & $4.25 \pm 0.09^{\mathrm{B}}$ & $3.68 \pm 0.19^{\mathrm{AB}}$ & $7.10 \pm 0.25^{\mathrm{A}}$ \\
\hline 14 & $4.56 \pm 0.12^{\mathrm{A}}$ & $3.79 \pm 0.18^{\mathrm{A}}$ & $7.43 \pm 0.27^{\mathrm{A}}$ \\
\hline 21 & $4.35 \pm 0.07^{\mathrm{AB}}$ & $3.38 \pm 0.17^{\mathrm{B}}$ & $5.96 \pm 0.31^{\mathrm{B}}$ \\
\hline \multicolumn{4}{|c|}{${ }^{\mathrm{a}-\mathrm{c}}$ Means $\pm \mathrm{SD}$ within the same column with different lowercase letters differ $(P<0.01)$. } \\
\hline \multicolumn{4}{|c|}{${ }^{\mathrm{A}-\mathrm{C}}$ Means $\pm \mathrm{SD}$ within the same column with different uppercase letters differ $(P<0.01)$} \\
\hline \multicolumn{4}{|c|}{$\begin{array}{l}{ }^{1} \mathrm{SGMPY}=\text { yogurt fortified with skim goat milk powder; } \mathrm{NaCnY}=\text { yogurt fortified with sodium caseinate; } \\
\text { WPCY = yogurt fortified with whey protein concentrate; WPIY = yogurt fortified with whey protein isolate; } \\
\text { YTIY = yogurt fortified with yogurt texture improver. Values within the columns are the averages of d } 1 \text { to } \\
21 \text { in triplicate. }\end{array}$} \\
\hline
\end{tabular}


SGMP was not the preferred one. Moreover, the yogurt with WPI had a lower score for odor and flavor $(P<$ 0.01) than that of the samples with $\mathrm{NaCn}, \mathrm{WPC}$, and YTI, even though it had higher acetaldehyde content than the threshold concentration of $8 \mathrm{ppm}$. This finding is in agreement with the results of Ott et al. (2000). These authors observed significant flavor differences between traditional acidic and mild, less acidic yogurts, and they concluded that acetaldehyde was only the one carbonyl compound that makes a contribution to yogurt aroma; therefore, the ultimate aromatic effect was from the combination of aromatic components and the acidity. Body and texture scores of all 5 yogurt samples decreased with the prolongation of storage, whereas the scores for odor and flavor increased up to $14 \mathrm{~d}$, panelist preference decreased on d 21.

\section{CONCLUSIONS}

The results showed that various milk protein-based products can be used for manufacturing GM yogurt with improved physical and sensorial quality. Yogurts fortified with either $\mathrm{NaCn}$ or YTI had more compact structure and lower syneresis than that yogurt fortified with WPC. Adding WPC or WPI resulted in an increase in the concentration of acetaldehyde in GM yogurt. Use of WPI did not improve the textural characteristics of the final product. Further investigations are needed for setting optimum $\mathrm{CN}$ :whey protein ratios in GM yogurt especially when fortification is made with whey-protein-based ingredients.

\section{ACKNOWLEDGMENTS}

The authors thank Ankara University Scientific Research Projects Coordination Unit (Project number 10B4347006) for financial assistance. We thank Arla Foods (Viby J, Denmark) for providing milk proteinbased ingredients. We also thank ABP Ltd. Co. (Ankara, Turkey) for providing the cone probe used for Texture Analyzer TA.XTPlus.

\section{REFERENCES}

Agnihotri, M. K., and V. S. S. Prasad. 1993. Biochemistry and processing of goat milk and milk products. Small Rumin. Res. 12:151-170.

Akalın, A. S., G. Unal, N. Dinkci, and A. A. Hayaloglu. 2012. Microstructural, textural, and sensory characteristics of probiotic yogurts fortified with sodium calcium caseinate or whey protein concentrate. J. Dairy Sci. 95:3617-3628.

Amatayakul, T., F. Sherkat, and N. P. Shah. 2006. Physical characteristics of set yoghurt made with altered casein to whey protein ratios and EPS-producing cultures at 9 and $14 \%$ total solids. Food Hydrocoll. 20:314-324.
AOAC International. 1997. Official Methods of Analysis. 15th ed. AOAC International, Washington, DC.

Asperger, H. 1977. Applicability of analytical methods for the assessment of yogurt quality. Dairy Sci. Abstr. 39:73.

Aziznia, S., A. Khosrowshahi, A. Madadlou, and J. Rahimi. 2008. Whey protein concentrate and gum tragacanth as fat replacers in nonfat yogurt: Chemical, physical, and microstructural properties. J. Dairy Sci. 91:2545-2552.

Barrantes, E., A. Y. Tamime, D. D. Muir, and A. M. Sword. 1994. The effect of substitution of fat by microparticulate whey protein on the quality of set-type yoghurt. J. Soc. Dairy Technol. 47:61-68.

Bodyfelt, F. W., J. Tobias, and G. M. Trout. 1988. The Sensory Evaluation of Dairy Products. Van Nostrand Reinhold, New York, NY.

Bradley, R. L., Jr., E. Arnold Jr., D. M. Barbano, R. G. Semerad, D. E. Smith, and B. K. Vines. 1993. Chemical and physical methods. Pages 433-531 in Standard Methods for the Examination of Dairy Products. R. T. Marshall, ed. American Public Health Association, Washington, DC.

Bucci, L., and L. Unlu. 2000. Proteins and amino acid supplements in exercise and sport. Pages 191-212 in Energy-Yielding Macronutrients and Energy Metabolism in Sports Nutrition. J. Driskell and I. Wolinsky, ed. CRC Press, Boca Raton, FL.

Chandan, R. C., P. J. Argyle, and G. E. Mathison. 1982. Action of Lactobacillus bulgaricus proteinase preparations on milk proteins. J. Dairy Sci. 65:1408-1413.

Chaves, A. C. S. D., M. Fernandez, A. L. S. Lerayer, I. Mierau, M. Kleerebezem, and J. Hugenholtz. 2002. Metabolic engineering of acetaldehyde production by Streptococcus thermophilus. Appl. Environ. Microbiol. 68:5656-5662.

Damin, M. R., M. R. Alcantara, A. P. Nunes, and M. N. Oliveira. 2009. Effects of milk supplementation with skim milk powder, whey protein concentrate and sodium caseinate on acidification kinetics, rheological properties and structure of nonfat stirred yoghurt. Food Sci. Technol. (Campinas.) 42:1744-1750.

Domagala, J. 2009. Instrumental texture, syneresis and microstructure of yoghurts prepared from goat, cow and sheep milk. Int. J. Food Prop. 12:605-615.

Domagala, J., M. Sady, T. Grega, and D. Najgebauer-Lejko. 2007. The Influence of texture improver type and its addition level on rheological properties of goat's milk yoghurt. Biotechnol. Anim. Husbandry 23:163-170.

Fiszman, S. M., M. A. Lluch, and A. Salvador. 1999. Effect of addition of gelatin on microstructure of acidic milk gels and yoghurt and on their rheological properties. Int. Dairy J. 9:895-901.

Gaafar, A. M. 1992. Volatile flavour compounds of yoghurt. Int. J. Food Sci. Technol. 27:87-91.

Guggisberg, D., P. Eberhard, and B. Albrecht. 2007. Rheological characterization of set yoghurt produced with additives of native whey proteins. Int. Dairy J. 17:1353-1359.

Guichard, E. 2002. Interactions between flavor compounds and food ingredients and their influence on flavor perception. Food Rev. Int. 18:49-70.

Guzman-Gonzales, M., F. Morais, and L. Amigo. 2000. Influence of skimmed milk concentrate replacement by dairy products in a lowfat set-type yogurt model system. II. Use of caseinates, co-precipitate and blended dairy powders. J. Sci. Food Agric. 80:433-438.

Gyosheva, B. H., and P. Rusev. 1979. Gas chromatography and spectral method application for the study of the Bulgarian yoghurt flavour. Nahrung 23:385-392.

Haenlein, G. F. W. 2004. Goat milk in human nutrition. Small Rumin. Res. 51:155-163.

Herrero, A. M., and T. Requena. 2006. The effect of supplementing goat's milk with whey protein concentrate on textural properties of set-type yoghurt. Int. J. Food Sci. Technol. 41:87-92.

Hruskar, M., N. Vahcic, and M. Ritz. 1995. Aroma profiles and sensory evaluation of yogurt during storage. Mljekarstvo 45:175-190.

Hull, M. F. 1947. Studies of milk proteins. II: Colorimetric determination of partial hydrolysis of the protein in milk. J. Dairy Sci. $30: 881-884$. 
International Dairy Federation (IDF). 1993. Determination of nitrogen content. Standard no. 20B. Int. Dairy Fed., Brussels, Belgium.

International Dairy Federation (IDF). 1997. Dairy Starter Cultures of Lactic Acid Bacteria (LAB). Standard no. 149A. Int. Dairy Fed., Brussels, Belgium.

Isleten, M., and Y. Karagul-Yuceer. 2006. Effects of dried dairy ingredients on physical and sensory properties of nonfat yogurt. J. Dairy Sci. 89:2865-2872.

Kang, Y.-J., J. F. Frank, and D. A. Lillard. 1988. Gas chromatographic detection of yogurt flavor compounds and changes during refrigerated storage. Cult. Dairy Products Int. 23:6-9.

Kondratenko, M., and B. Gyosheva. 1978. Changes in volatile components of Bulgarian yogurt. Lait 58:390-396.

Kwak, H. S. 1995. Effect of volatile flavor compound on yogurt during refrigerated storage. Korean J. Food Sci. Technol. 27:939-943.

Laye, I., D. Karleskind, and C. V. Morr. 1993. Chemical, microbiological and sensory properties of plain nonfat yogurt. J. Food Sci. 58:991-995.

Lee, W. J., and J. A. Lucey. 2010. Formation and physical properties of yogurt. Asian-australas. J. Anim. Sci. 23:1127-1136.

Lees, G. J., and G. R. Jago. 1976. Acetaldehyde: An intermediate in the formation of ethanol from glucose by lactic acid bacteria. J. Dairy Res. 43:63-73.

Li, J. C., and M. R. Guo. 2006. Effects of polimerized whey proteins on consistency and water-holding properties of goat's milk yogurt. J. Food Sci. 71:34-38.

Marshall, V. M., and W. M. Cole. 1983. Threonine aldolase and alcohol dehydogenase activities in Lactobacillus bulgaricus and Lactobacillus acidophilus and their contribution to flavour production in fermented milks. J. Dairy Res. 50:375-379.

Marshall, V. M., and E. El-Bagoury. 1986. Use of ultrafiltration and reverse osmosis to improve goats' milk yogurt. J. Soc. Dairy Technol. 39:65-66.

McComas, K. A., and S. E. Gilliland. 2003. Growth of probiotic and traditional yoghurt cultures in milk supplemented with whey protein hydrolyzate. J. Food Sci. 68:2090-2095.

Mistry, V. V., and H. N. Hassan. 1992. Manufacture of nonfat yogurt from a high milk protein powder. J. Dairy Sci. 75:947-957.

Modler, H. W., M. E. Larmond, C. S. Lin, D. Froelich, and D. B. Emmons. 1983. Physical and sensort properties of yogurt stabilized with milk proteins. J. Dairy Sci. 66:422-429.

Oliveira, M. N., I. Sodini, F. Remeuf, and G. Correu. 2001. Effect of milk supplementation and culture composition on acidification, textural properties and microbiological stability of fermented milks containing probiotic bacteria. Int. Dairy J. 11:935-942.

Ott, A., A. Hugi, M. Baumgartner, and A. Chaintreau. 2000. Sensory investigation of yogurt flavor perception: mutual influence of volatiles and acidity. J. Agric. Food Chem. 48:441-450.

Park, Y. W., M. Juarez, M. Ramos, and G. F. W. Haenlein. 2007. Physico-chemical characteristics of goat and sheep milk. Small Rumin. Res. 68:88-113.

Puvanenthiran, A., R. P. W. Williams, and M. A. Augustin. 2002. Structure and visco-elastic properties of set yoghurt with altered casein to whey protein ratios. Int. Dairy J. 12:383-391.

Rasic, J. L., T. Stojsavljevic, and R. Curcic. 1971. A study on the amino acids of yogurt. II. Amino acid content and biological value of the proteins of different kinds of yogurt. Milchwissenschaft 26:219-224.

Raya, R. R., M. C. M. Nadra, A. P. R. Hoigado, and G. Oliver. 1986. Acetaldehyde metabolism in lactic acid bacteria. Milchwissenschaft 41:397-399.
Raynal-Ljutovac, K., G. Lagriffoul, P. Paccard, I. Guillet, and Y. Chilliard. 2008. Composition of goat and sheep milk products: An update. Small Rumin. Res. 79:57-72.

Remeuf, F., and J. Lenoir. 1986. Relationship between the physicochemical characteristics of goat's milk and its rennetability. Pages 68-72 in Bull. IDF no. 202. Int. Dairy Fed., Brussels, Belgium.

Renner, E. 1993. Milchprakticum. Justus-Liebig-Universität, Giessen, Germany.

Riberio, A. C., and S. D. A. Riberio. 2010. Specialty products made from goat milk. Small Rumin. Res. 89:225-233.

Robitaille, G., A. Tremblay, S. Moineau, D. St-Gelais, C. Vadeboncoeur, and M. Britten. 2009. Fat-free yogurt made using a galactose-positive exopolysaccharide-producing recombinant strain of Streptococcus thermophilus. J. Dairy Sci. 92:477-482.

Routray, W., and H. N. Mishra. 2011. Scientific and technical aspects of yogurt aroma and taste: A review. Compr. Rev. Food Sci. Food Saf. 10:208-220.

Rysstad, G., W. J. Knutsen, and R. K. Abrahamsen. 1990. Effect of threonine and glycine on acetaldehyde formation in goat's milk yogurt. J. Dairy Res. 57:401-411.

Saint-Eve, A., A. Juteau, S. Atlan, N. Martin, and I. Souchon. 2006. Complex viscosity induced by protein composition variation influences the aroma release of flavoured stirred yoghurt. J. Agric. Food Chem. 54:3997-4004

Sindayikengera, S., and W. Xia. 2006. Nutritional evaluation of caseins and whey proteins and their hydrolysates from Protameks. J. Zhejiang Univ. Sci. B 7:90-98.

Singh, M., and J. A. Byars. 2009. Starch-lipid composites in plain set yogurt. Int. J. Food Sci. Technol. 44:106-110.

Slocum, S. A., E. M. Jasinski, and A. Kilara. 1988. Processing variables affecting proteolysis in yoghurt during incubation. J. Dairy Sci. 71:596-603.

Sullivan, S. T., S. A. Khan, and A. S. Eissa. 2008. Whey protein: Functionality and foaming under acidic conditions. Pages 99-132 in Whey Processing, Functionality and Health Benefits. C. I. Onvulata and P. J. Huth, ed. Wiley-Blackwell, Ames, IA.

Tamime, A. Y., and H. C. Deeth. 1980. Yogurt: Technology and biochemistry. J. Food Prot. 43:939-977.

Tamime, A. Y., and R. K. Robinson. 2007. Yoghurt: Science and Technology. 3rd ed. CRC Press, Boca Raton, FL.

Tramer, J. 1973. Yogurt cultures. J. Soc. Dairy Technol. 26:16-21.

Tribby, D. 2009. Yogurt. Pages 191-224 in The Sensory Evaluation of Dairy Products. S. Clark, M. Costello, M. A. Drake, and F. Bodyfelt, ed. Springer Science+BusinessMedia LLC, New York, NY.

Ulberth, F. 1991. Headspace gas chromatographic estimation of some yogurt volatiles. J. Assoc. Off. Anal. Chem. 74:630-643.

Wang, W., Y. Bao, G. M. Hendricks, and M. Gou. 2012. Consistency, microstructure and probiotic survivability of goats' milk yoghurt using polymerized whey protein as a co-thickening agent. Int. Dairy J. 24:113-119.

Wilkins, D. W., R. H. Schmidt, R. B. Shireman, K. L. Smith, and J. J. Jezeski. 1986. Evaluating acetaldehyde synthesis from L-[14C(U)] threonine by Streptococcus thermophilus and Lactobacillus bulgaricus. J. Dairy Sci. 69:1219-1224.

Zouari, A., J. P. Accolas, and M. J. Desmazeaud. 1992. Metabolism and biochemical characteristics of yogurt bacteria. A review. Lait $72: 1-34$. 